\title{
An Expedient Synthesis of Oxazepino and Oxazocino Quinazolines
}

Albertus Wijnand Hensbergen ${ }^{a}$, Vanessa, R. Mills ${ }^{a}$, Ian Collins ${ }^{b}$ and Alan M. Jones ${ }^{a, *}$

a Division of Chemistry and Environmental Science, School of Science and the Environment, Faculty of Science and Engineering, Manchester Metropolitan University, John Dalton Building, Chester Street, Manchester, Lancashire, M1 5GD, United Kingdom

b Cancer Research UK Cancer Therapeutics Unit, The Institute of Cancer Research, London SM2 5NG, United Kingdom

\section{Graphical Abstract}<smiles>N#Cc1c(N)cccc1F</smiles>

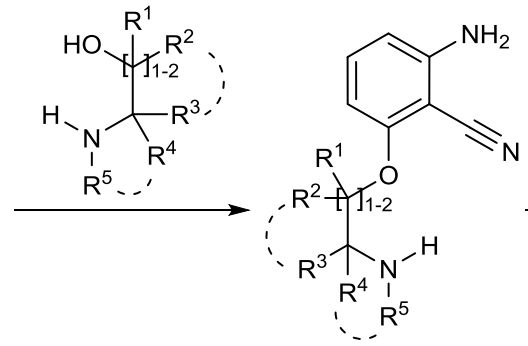<smiles>[R]C([R])(Oc1cccc2nc[nH]c(=O)c12)C([R])([R])N1CCCC1</smiles>

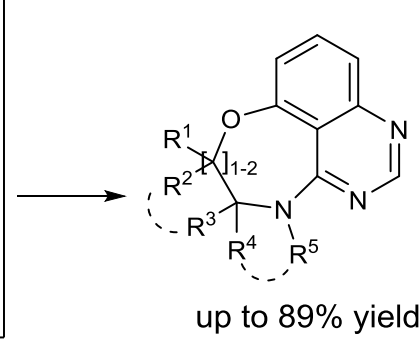

Abstract

A synthetic route to a new class of privileged tri- and tetra-cyclic quinazolines containing a medium-sized ring is reported. An expedient synthetic route involving nucleophilic aromatic substitution, and sequential Niementowski and BOP-mediated ring closures afforded a collection of analogues. The scope of the reaction was explored in terms of cyclic and acyclic linkers, ring size and substitution pattern.

\section{Keywords}

Niementowski reaction; Quinazoline; Heterocycle; Cyclisation; Medium-ring

\section{Introduction}

Quinazolines belong to a privileged class of bioactive small molecules, ${ }^{1}$ which are found in a collection of natural products ${ }^{2}$ and interact with a variety of important biological targets ${ }^{3}$ including tankyrase-1 protein $^{4}$ (as a senescence inducer), aswell as

* Corresponding author. Dr Alan M. Jones; Tel.: +44-(0)161-247-6195; e-mail: A.M.Jones@mmu.ac.uk; web: www.jonesgroupresearch.wordpress.com 
various anticonvulsant ${ }^{5}$ and antifungal targets. ${ }^{6}$ Most notably, several substituted quinazolines act as anti-cancer ATP-competitive kinase inhibitors. ${ }^{7-11}$ Examples of quinazoline containing drugs on the market (Figure 1) include gefitinib (also known as Iressa $\left.{ }^{\circledR}\right)^{12,13}$ and laptinib ${ }^{14}$ (for HER2+ / EGFR+ and ER+ advanced breast cancer treatment).

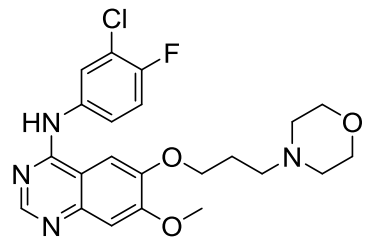

Gefitinib

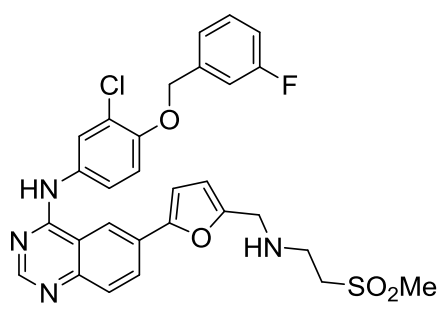

Laptinib

Figure 1. Selected examples of quinazoline containing anti-cancer drugs.

As part of a medicinal chemistry research programme, we required a method to synthesise medium ring containing oxazepino[5,6,7-de]quinazolines with increased $\mathrm{Fsp}^{3}$ (fraction of $\mathrm{sp}^{3}$ hybrid atoms) content as a surrogate measure of complexity, thus accessing new 3D pharmacophores with potentially improved solubility and increasing the chance of discovering new biologically relevant space. ${ }^{15,16}$ Medium-ring containing molecules are challenging to synthesise due to competing effects arising from loss of entropy, Pitzer, Baeyer and transannular strain. ${ }^{17,18}$ In particular there is a paucity of information regarding the synthesis of oxazepino[5,6,7-de]quinazolines, and to date, the only four examples have been reported by Bradbury and co-workers ${ }^{19,20}$ using Thorpe-Ingold and pseudo-Thorpe-Ingold cyclisation assistance to prepare quinazolines with a 7-membered amide ring junction (Figure 2). Encouragingly, these examples showed potent inhibition of both EGFR (epidermal growth factor receptor) and erbB2 tyrosine kinase protein phosphorylation. Inhibition of the phosphorylation of erbB2 in the MCF7 breast cancer cell line was also demonstrated. ${ }^{21}$ 

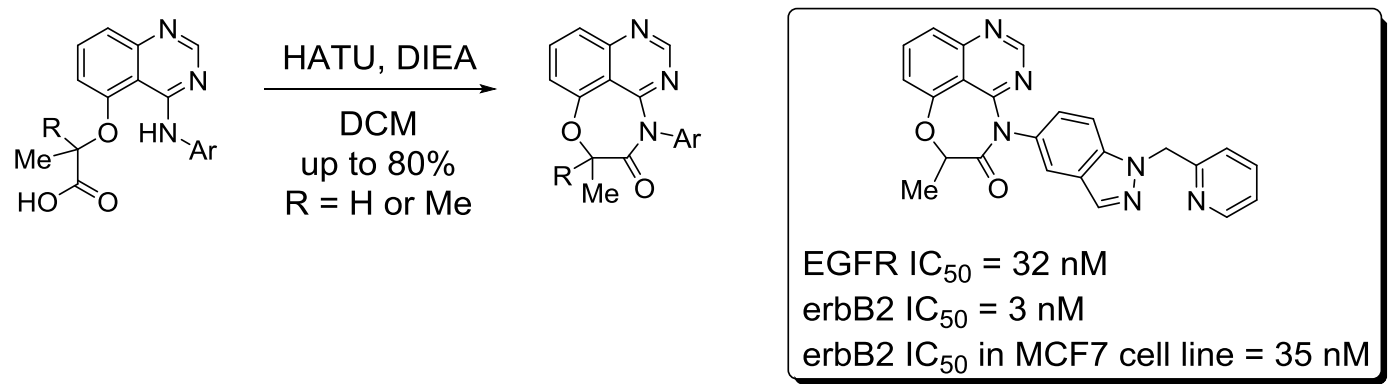

Figure 2. Previously reported synthesis of oxazepino[5,6,7-de]quinazolines and a representative example of their associated erbB2 and EGFR tyrosine kinase protein phosphorylation inhibition.

The binding mode and/or a small molecule-erbB2 protein crystal structure have not been published on the protein data bank (PDB). ${ }^{22}$ Comparison with other reported small molecule-erbB2 inhibitors crystal structures (PDB codes: 3PP0, 4LRM and 4G5J) suggested that the $N 1$ nitrogen of the quinazoline would make a hydrogen bond accepting contact with the methionine residue in the ATP-dependent active site and act as an activity anchor. Encouraged by this, we investigated a concise synthesis of a more general class of oxazepino[5,6,7-de]quinazolines using the disconnection approach detailed in Scheme 1.

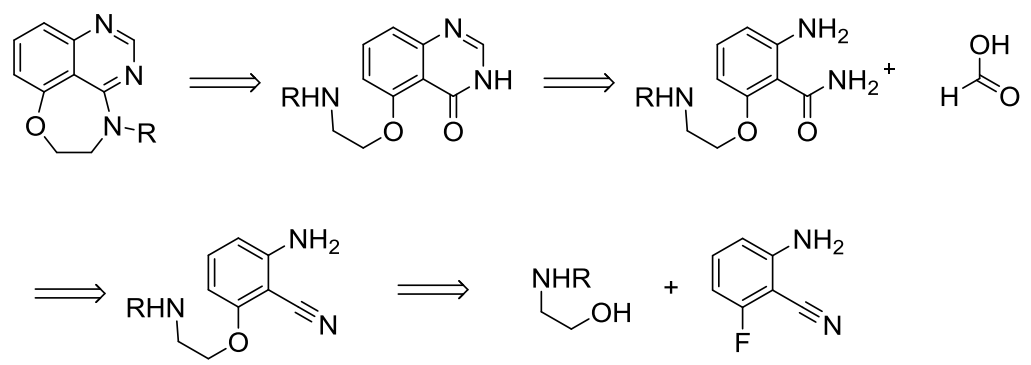

Scheme 1. Proposed disconnection strategy to a new class of oxazepino[5,6,7-de]quinazolines.

It was envisioned to generate diversity ${ }^{15}$ through the 5-O- attachment position, from one of a number of commercially available aminoalcohols. These have been installed via $\mathrm{SNAr}_{\mathrm{N}}$ chemistry with preference for O-substitution ${ }^{23}$ on a suitably functionalised fluorobenzonitrile. The quinazoline group could be part-assembled via a number of reported $4(3 H)$-quinazolinone syntheses ${ }^{24,25}$ such as the Niementowski reaction. ${ }^{26}$ The completion of the synthesis relied on identifying a suitable coupling agent for the intra-molecular cyclisation ${ }^{27}$ between a primary or secondary amine group and a 
heteroaromatic amide in preference to polymeric cyclisation. The non-cyclic reaction of an amine and heteroaromatic amide has recently been evaluated with a range of amide bond coupling agents. ${ }^{28}$

\section{Results and Discussion}

To probe the feasibility of the proposed disconnection strategy we investigated a synthetic route to an example quinazoline (3a) as shown in Scheme 2. Using 2-amino6-fluorobenzonitrile, an $S_{N} A r$ reaction with a protected amino alcohol afforded the key starting material 1a in a modest yield. A Niementowski-type cyclisation of 1a in a mixture of formic and sulfuric acid at reflux afforded $\mathbf{2 a}$ in sufficient yield to attempt the final cyclisation of the secondary amine with the pre-installed amide group. The choice of amide bond coupling agent has been shown to be critical to the type of the product formed (see HATU vs HBTU), ${ }^{28}$ and we found that BOP operated in the same manner as HBTU to afford $3 \mathbf{a}$ in good yield.

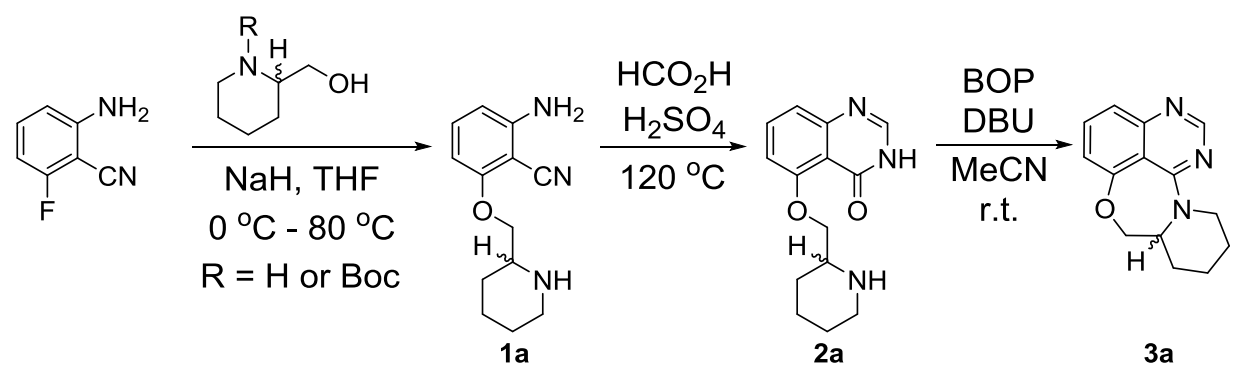

Scheme 2. Preparation of oxazepinoquinazoline scaffold 3a. Yields are reported and discussed in Tables 1 and 3.

Encouraged by this result, we next looked to explore a diverse range of amino alcohols with which to react with 6-fluorobenzonitrile to probe the scope of the tandem cyclisation strategy.

The selection of amino alcohol would probe the parameters of the Niementowski (2) and BOP (3) mediated ring closures (Table 3 ). The previously reported ${ }^{23} \mathrm{~S}_{N} \mathrm{Ar}$ reaction of 6-fluoro-2-aminobenzonitrile with a limited selection of aminoalcohols generally proceeded in modest to good yields (Table 1). 
Table 1. Isolated yields for the $S_{N} A r$ reactions.

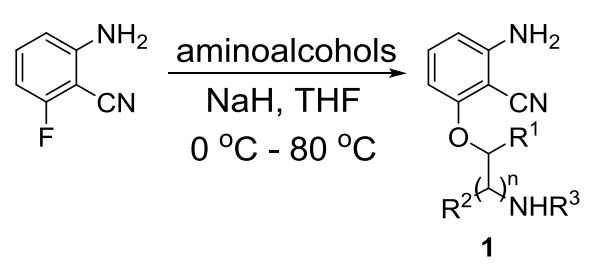

Entry


7<smiles>CC(N)CO</smiles><smiles>CC(N)COc1cccc(N)c1C#N</smiles>

8<smiles>CC(C)(N)CO</smiles>

$9 a$

$9 b$

10<smiles>CC(O)CN</smiles>

11<smiles>CC(C)(N)COc1cccc(N)c1C#N</smiles>

65

53

n.d. ${ }^{b}$

72

44<smiles>CC(CN)Oc1cccc(N)c1C#N</smiles><smiles>N#Cc1ccccc1OCc1ccc(N)cc1</smiles>

25

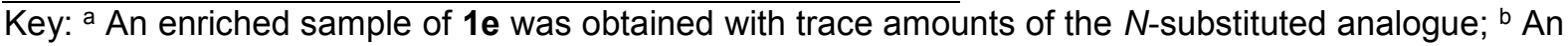
inseparable 2:1 mixture of 2-amino-6-(3-aminopropoxy)benzonitrile and 2-amino-6-(3hydroxypropylamino)benzonitrile was obtained.

To aid purification of the diaminonitrile products (1), N-tert-butylcarboxy protection of the amino alcohol prior to treatment with sodium hydride was examined. The protecting group was smoothly installed under standard conditions. However, the $\mathrm{N}$ tertbutylcarboxy group was found to be readily cleaved under the reaction conditions on both primary and secondary amines (entries 1a, 6a and 9a).

Comparison of the yields between protected and unprotected amines revealed a 2.5fold improvement in yield for the unprotected secondary amine (entries 1a vs 1b). In the case of a primary amine vs the protected carbamate (entries 6a vs 6b and 9a vs 9b) showed that either no desired product could be isolated from the complex reaction mixture or a 2:1 inseparable mixture of $\mathrm{O}$ - and $\mathrm{N}$ - SNAr products resulted. This was presumably caused by the increasing acidity of the carbamate $\mathrm{NH}$ group, resulting in the removal of a proton using sodium hydride, allowing an alternative $S_{N} A r$ reaction 
pathway for the conjugate base of the hydroxyl group to substitute the ipso fluorine atom. Although the Niementowski reaction has been extensively explored and reviewed, ${ }^{29-31}$ details regarding the mechanism are less clear despite the apparent simplicity of the reaction components. ${ }^{32,33}$

Table 2 shows that in our system, portion-wise addition of the organic starting material afforded high conversion. However, addition in one portion afforded a similar high conversion but proved capricious on scale. The best balance when using small quantities of the organic component was found to be to dissolve $\mathbf{2}$ in formic acid to facilitate the drop-wise addition.

Table 2. Optimisation of the Niementowski quinazoline ring synthesis (conversion measured by ${ }^{1} \mathrm{H}$ NMR spectroscopy).

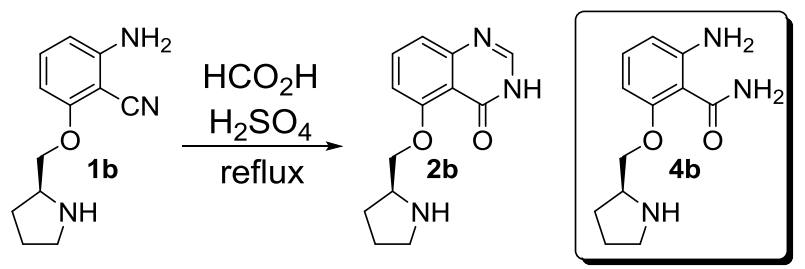

\begin{tabular}{lll}
\hline Entry & Conditions & $\begin{array}{l}\text { Conversion } \\
(\%) \text { after } 2 \mathrm{~h}\end{array}$ \\
\hline 1 & (B1) Addition of 1b from t = 0 min & 60 \\
2 & (B2) Portion-wise addition of 1b & 63 \\
3 & (B3) Portion-wise addition of 1b in formic & 72 \\
& acid &
\end{tabular}

Key: B1, B2, B3 general conditions are detailed in the accompanying ESI.

During the course of our studies into the Niementowski ring closure reaction and subsequent functionalization we observed the formation of an amide by-product (e.g. 4b), either resulting from acid-mediated hydrolysis by adventitious water or as a reaction intermediate. Of note, re-submission of the amide (4b) to the reaction mixture yielded the Niementowski product $(\mathbf{2} \mathbf{b})$, giving further support to the most recent 
enquiry into the mechanism which demonstrated that a benzamide intermediate formed via a slower reaction pathway. ${ }^{33}$

Furthermore we noted during our optimisation studies (Table 2) that the reaction proceeded in higher yield in a sealed system (a crimped microwave vial) in comparison to a round bottom flask under an inert atmosphere. ${ }^{34}$ We therefore, designed an experiment to explore if the Niementowski reaction is in fact a carbon monoxidemediated reaction. The literature was found to be inconsistent in terms of parameters such as portion-wise addition of starting materials, sealed or open reaction vessels and having the mixed acids heated to reflux prior to addition of the organic starting component. The possibility that the aminobenzamide formed from acid-catalysed hydrolysis of the benzonitrile ${ }^{35}$ which in turn may intercept carbon monoxide was intriguing. It has been reported ${ }^{36-40}$ that under particular conditions both $\mathrm{CO}_{2}$ and $\mathrm{CO}$ could be sequestered by an aminobenzamide to form a quinazoline-2,4(1H,3H)-dione. In our hands, usinf a model system (anthranilamide) under 1 atmosphere of $\mathrm{CO}$ in refluxing sulfuric acid no evidence of ring closure was observed for the Niementowski reaction.

Our attention turned next to the generality of the tandem Niementowski and BOP mediated sequential ring closures of 1 to give $\mathbf{3}$ (via 2 ) and are reported in Table 3.

Despite the improvements in yield shown in Table 2, in some cases purification (flash silica gel and/or ion-exchange chromatography) remained an issue and therefore telescoping the Niementowski product (2) after isolation, but not purification, onto the BOP-mediated ring closure, improved the two-step yield as shown in Table 3. 
Table 3. Tandem cyclisation reactions.

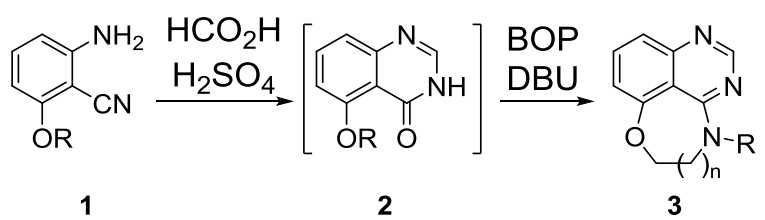

Entry Substrate<smiles>N#Cc1c(N)cccc1CN1CCCCC1COc1cccc(N)c1C#N</smiles>

3<smiles>CNCCOc1cccc(N)c1C#N</smiles>

4<smiles>N#Cc1c(N)cccc1CCC1CCCCN1</smiles>

5<smiles>N#Cc1c(N)cccc1OCCNc1ccccc1</smiles>

6<smiles>N#Cc1c(N)cccc1OCN</smiles>

Conditions

Yield of 2a-m Product 3

Yield of 3a-m (\%) $(\%)^{\mathrm{a}}$

$\begin{array}{ll}\text { B1 } & 14 \% \\ \text { B2 } & 83 \% \\ \text { B3 } & 80 \%\end{array}$<smiles>c1cc2c3c(ncnc3c1)N1CCCCN21</smiles>

$71 \%$

$65 \%$

$66 \%$

B3

$35 \%{ }^{c}$<smiles>c1cc2c3c4nc(nc3c1)C(=N4)CCC2</smiles>

$52 \%$

(18\%, 2 steps)

$60 \%$ (2 steps)<smiles>CN1CCOc2cccc3ncn1c23</smiles>

B3

$55 \%$

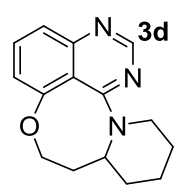

$89 \%$

(49\%, 2 steps)

25\% (2 steps)

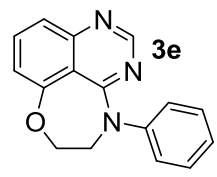

B3

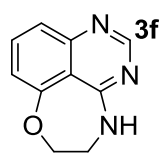


7<smiles>CC(N)COc1cccc(N)c1C#N</smiles>

8<smiles>CC(C)(N)COc1cccc(N)c1C#N</smiles>

9<smiles>N#Cc1c(N)cccc1OCCCN</smiles>

10<smiles>CC(CN)Oc1cccc(N)c1C#N</smiles>

11

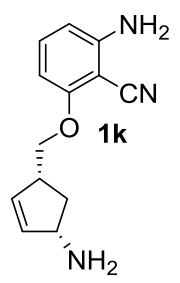

B3

B3

B3

B3

B3
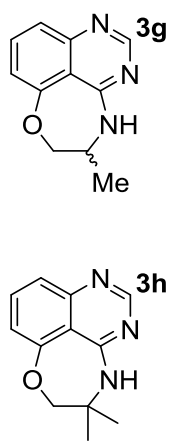

$<5 \%$ conversion $^{\text {d }}$

32\% (2-steps)

$<5 \%$ conversion $^{\text {d }}$
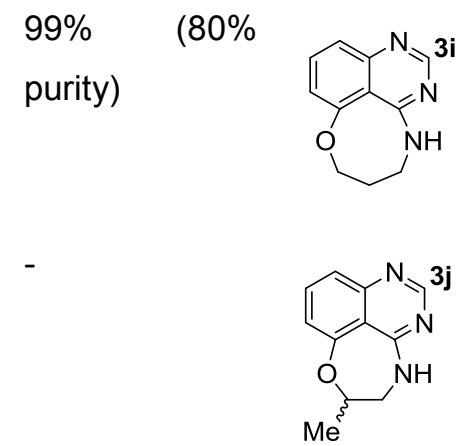

$0 \%{ }^{\mathrm{d}, \mathrm{e}}$

$0 \%$ a

Key: B1, B2 or B3 refer to the Niementowski conditions as described in Table 2 and the ESI; a Purified and isolated yield for intermediates 2; ${ }^{\mathrm{b}}$ Purified and Isolated yield for products 3; ${ }^{\mathrm{c}}$ Terminating the reaction at $t=30 \mathrm{~min}$ led to isolation of the amide intermediate $(\mathbf{4 b})$; ${ }^{d}$ Decomposition products were

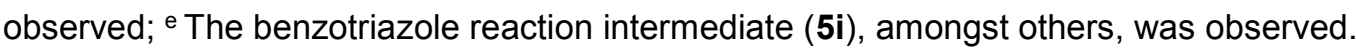

As the original structure $3 \mathbf{a}^{41}$ (entries $1 \mathrm{a}-\mathrm{c}$ ) was based on a cyclic amino alcohol, we sought to investigate whether this group could be varied in size (changing piperidine to pyrrolidine; entries 1 and 2) which gratifyingly proceeded in good yield. We also probed whether a pseudo-Thorpe-Ingold effect of an a-ring system encouraged a 7ring cyclisation. Removal of the piperidine ring system to give the alkyl chain secondary amino alcohol (entries 1 vs 3 ) gave an analogous yield of the ring closure product.

Thus far, only secondary amines were used (entries 1-5). To probe whether primary amines were also suitable (entries 6-11) these were also subjected to the tandem 
cyclisation strategy with mixed results. For instance the Thorpe-Ingold assisted product $3 \mathrm{~h}$ (entry 8 ) proceeded in a modest $32 \%$ yield over two-steps. Contrary, to the data obtained in the secondary amine system (entries 3 vs 1 and 2) removal of one methyl group in the primary amine system (entry 7), only showed trace conversion to product. Moving the methyl group adjacent to the oxa-position was also detrimental to the reaction success (entry 10). However, the unsubstituted alkyl chain in entry 6 proceeded in excellent yield over two-steps.

The formations of 8 membered and above ring systems are significantly more challenging targets in synthesis. By drawing analogy with the linear alkyl chain example, homologated amino alcohols (entries 4 and 9) would deliver the comparison to the 7-ring (entries 1 and 6). Molecular mechanics (MM2) optimisation of the structures suggested the 8-ring system would be the limit of accessible cyclisation conformations when fused to a bicyclic quinazoline ring system. To our delight, the tetracyclic 8-ring system (entry 4) formed in excellent yield. However, the acyclic analogue (entry 9) failed to deliver the desired cyclic product. The dichotomy in conversion between the acyclic and cyclic amino examples may be a result of the now accentuated difference in pseudo Thorpe-Ingold effects between the $\alpha-\mathrm{H}$ and $\alpha$-ring systems. Intriguingly, investigation of the reaction mixture revealed the presence of $5 \mathbf{i}$ confirming the postulated reaction mechanism (Scheme 3). ${ }^{28}$

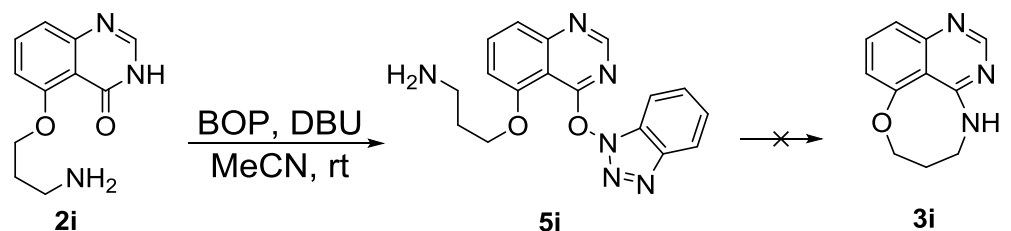

Scheme 3. A limitation of the methodology and ${ }^{1} \mathrm{H}$ NMR spectroscopic observations of reaction intermediate $\mathbf{5 i}$.

A probe compound (entry 11) was attempted to form a more strained product. However, this did not afford the desired Niementowski reaction product and instead degradation was observed. It was also found that neither 2- nor 4-aminocyclohexanol afforded the Niementowski intermediate. 
Finally, to demonstrate the possibility of examples of $\mathrm{N}$-substitution at the 4-position which did not use $\mathrm{H}$ or methyl, a phenyl example was introduced (entry 5) in good yield.

Evidence for the desired transformation from the quinazolin(4H)one $(2)^{42}$ to give the cyclised 4-aminoquinazoline $(3)^{43}$ was gathered not only from the loss of the amide carbonyl peak but also the diagnostic downfield shift of the $H 2$ proton as detailed in Table 4, indicating connection of the aliphatic amino termini to the activated quinazolin(4H)one ring system (3).

Table 4. Downfield shift of the diagnostic singlet aromatic proton $H 2$ signal upon cyclisation of secondary amine examples of 2 as measured by ${ }^{1} \mathrm{H}$ NMR spectra.

\begin{tabular}{lll}
\hline $\begin{array}{l}\text { Starting } \\
\text { material }\end{array}$ & Product & $\pm \mathrm{ppm}$ \\
\hline $\mathbf{2 a}$ & $\mathbf{3 a}$ & +0.35 \\
$\mathbf{2 b}$ & $\mathbf{3 b}$ & +0.21 \\
$\mathbf{2} \mathbf{b}$ & $\mathbf{3 c}$ & +0.39 \\
$\mathbf{2 d}$ & $\mathbf{3 d}$ & +0.19 \\
$\mathbf{2 e}$ & $\mathbf{3 e}$ & +0.27 \\
\hline
\end{tabular}

Representative examples of the final compounds (3a-d, $\mathbf{3 f}$ and $\mathbf{3 h}$ ) were tested for anti-proliferative effects using MCF7, BT474 and MDA-MB231 breast cancer cell lines, however none showed effects in the submicromolar range. ${ }^{44}$ Further development of this new compound class and its application to other biological targets are currently underway and will be reported in due course.

\section{Conclusions}

In the present study, we have identified a straightforward three-step route to a new class of oxazepino and oxazecino quinazolines. We have demonstrated the SNAr of a fluorobenzonitrile with a range of commercially available aminoalcohols followed by sequential Niementowski and BOP-mediated ring closure to afford a collection of rigidified analogues. This remarkable tandem cyclisation strategy is a new and 
enabling route to rigidify kinase inhibitor-like quinazolines and has wide-ranging potential in the field of medicinal chemistry.

\section{Acknowledgments}

The authors thank Manchester Metropolitan University for funding and Dr Swee Sharp at the Institute of Cancer Research (London) for biological evaluation of $\mathbf{3 a - d ,} \mathbf{3} \mathbf{f}$ and 3h using MCF7, BT474 and MDA-MB231 cancer cell lines. The authors thank the analytical services at MMU and ICR for performing NMR and MS analyses. A.W.H thanks the Erasmus+ Scholarship scheme and the University of Applied Sciences, Utrecht, The Netherlands.

\section{Supplementary Material}

Supplementary data (experimental details and characterization of novel compounds) associated with this article can be found, in the online version, at $\mathrm{xxx}$.

\section{References and Notes}

1. Marzaro, G.; Guiotto, A.; Chilin, A. Expert Opin. Ther. Patents 2012, 22, 223.

2. Shakhidoyatov, K. M.; Elmuradov, B. Z. Chem. Nat. Compd. 2014, 50, 781.

3. Wang, D.; Gao, F. Chem. Cent. J. 2013, 7, 95.

4. Kamal, A.; Sultana, F.; Ramaiah, M. J.; Srikanth, Y. V. V.; Viswanath, A.; Bharathi, E. V.; Nayak, R.; Pushpavalli, S. N. C. V. L.; Srinivas, C.; Pal-Bhadra, M. MedChemComm 2013, 4, 575.

5. Ugale, V. G.; Bari, S. B. Eur. J. Med. Chem. 2014, 80, 447.

6. Kathiravan, M. K.; Salake, A. B.; Chothe, A. S.; Dudhe, P. B.; Watode, R. P.; Mukta, M. S.; Gadhwe, S. Bioorg. Med. Chem. 2012, 20, 5678.

7. Bridges, A. J. Chem. Rev. 2001, 101, 2541.

8. Klebl, B. M.; Muller, G. Expert Opin. Ther. Targets 2005, 9, 975.

9. Zhang, J.; Yang, P. L.; Gray, N. S. Nat. Rev. Cancer 2009, 9, 28.

10. Laird, A. D.; Cherrington, J. M. Expert Opin. Invest. Drugs 2003, 12, 51.

11. Zuccotto, F.; Ardini, E.; Casale, E.; Angiolini, M. J. Med. Chem. 2010, 53, 2681.

12. Barker, A. J.; Gibson, K. H.; Grundy, W.; Godfrey, A. A.; Barlow, J. J.; Healy, M. P.; Woodburn, J. R.; Ashton, S. E.; Curry, B. J.; Scarlett, L.; Henthorn, L.; Richards, L. Bioorg. Med. Chem. Lett. 2001, 11, 1911.

13. Gibson, K. H.; Grundy, W.; Godfrey, A.; Woodburn, J. R.; Ashton, S. E.; Curry, B. J.; Scarlet, L.; Barker, A. J.; Brown, D. S. Bioorg. Med. Chem. Lett. 1997, 7, 2723.

14. Petrov, K. G.; Zhang, Y. M.; Carter, M.; Cockerill, G. S.; Dickerson, S.; Gauthier, C. A.; Guo, Y.; Mook, R. A., Jr.; Rusnak, D. W.; Walker, A. L.; Wood, E. R.; Lackey, K. E. Bioorg. Med. Chem. Lett. 2006, 16, 4686. 
15. Collins, I.; Jones, A. M. Molecules 2014, 19, 17221.

16. Lovering, F.; Bikker, J.; Humblet, C. J. Med. Chem. 2009, 52, 6752.

17. Jones, A. M.; Liu, G.; Lorion, M. M.; Patterson, S.; Lebl, T.; Slawin, A. M.; Westwood, N. J. Chem. Eur. J. 2011, 17, 5714.

18. Hussain, A.; Yousuf, S. K.; Mukherjee, D. RSC Adv. 2014, 4, 43241.

19. Bradbury, R. H.; Kettle, J. G.; Scott, J. S.; Barlaam, B. C. PCT Patent, WO 2005/118572 A1 2005.

20. Bradbury, R. H.; Barlaam, B. C.; Ducray, R. PCT Patent, WO 2007/034144 2007.

21. Roskoski, R., Jr. Pharmacol. Res. 2014, 87, 42.

22. RCSB Protein Data Bank can be found at http://www.rcsb.org/pdb

23. Tachdjian, C.; Tang, X. Q.; Karanewsky, D. S.; Servant, G.; Li, X.; Zhang, F.; Chen, Q.; Zhang, H.; Davis, T.; Darmohusodo, V.; Wong, M.; Selchau, V. PCT Int. Appl. WO 2011123693 A1 201110062011.

24. Baumann, M.; Baxendale, I. R. Beilstein J. Org. Chem. 2013, 9, 2265.

25. He, L.; Li, H.; Chen, J.; Wu, X.-F. RSC Adv. 2014, 4, 12065.

26. Niementowski, S. J. Prakt. Chem. 1895, 51, 564.

27. Jones, A. M. Molbank 2015, M859.

28. Xiao, Z.; Yang, M. G.; Li, P.; Carter, P. H. Org. Lett. 2009, 11, 1421.

29. Kidwai, M.; Rastogi, S.; Mohan, R.; Ruby. Croat. Chem. Acta 2003, 76, 365.

30. Loidreau, Y.; Besson, T. Tetrahedron 2011, 67, 4852.

31. Kundu, S. K.; Mahindaratne, M. P. D.; Quintero, M. V.; Bao, A.; Negrete, G. R. ARKIVOC 2008, 33.

32. Roth, G. A.; Tai, J. J. J. Het. Chem. 1996, 33 2051-2053.

33. Layeva, A. A.; Nosova, E. V.; Lipunova, G. N.; Trashakhova, T. V.; Charushin, V. N. Russ. Chem. Bull., Int. Ed. 2007, 56, 1821.

34. CAUTION It should be noted that the mixing of formic acid with strong acids liberates carbon monoxide, as witnessed by the evolution of a gas upon mixing.

35. Suzuki, T.; Oka, M.; Maeda, K.; Furusawa, K.; Uesaka, H.; Kataoka, T. Chem. Pharm. Bull. 1999, 47, 28.

36. Jacquet, O.; Das Neves Gomes, C.; Ephritikhine, M.; Cantat, T. ChemCatChem 2013, 5, 117.

37. Miyata, T.; Mizuno, T.; Nagahama, Y.; Nishiguchi, I.; Hirashima, T. Heteroat. Chem. 1991, 4, 473.

38. Bassoli, A.; Rindon, B.; Tollari, S. J. Mol. Cat. 1990, 60, 41.

39. Kihlberg, T.; Karimi, F.; Långstrom, B. J. Org. Chem. 2002, 67, 3687.

40. Mizuno, T.; Toba, H.; Miyata, T.; Nishiguchi, I. Heteroat. Chem. 1994, 5, 437.

41. Experimental procedure: synthesis of $8,8 a, 9,10,11,12-$ Hexahydropyrido[2',1':3,4][1,4]oxazepino[5,6,7-de]quinazoline (3a) Sodium hydride $60 \% \mathrm{w} / \mathrm{w}$ in oil, $87 \mathrm{mg}, 2.28 \mathrm{mmol}$ ) was added portionwise to $\mathrm{N}$-Bocpiperidine-2-methanol $(0.49 \mathrm{~g}, 2.28 \mathrm{mmol})$ in THF $(7.6 \mathrm{~mL})$ at $0^{\circ} \mathrm{C}$ over a period of $10 \mathrm{~min}$. The resulting solution was stirred at $0{ }^{\circ} \mathrm{C}$ for $1 \mathrm{hr}$. Then, 2-amino-6fluorobenzonitrile $(0.28 \mathrm{~g}, 2.05 \mathrm{mmol})$ was added in one-portion and the mixture heated at $85^{\circ} \mathrm{C}$ for $2 \mathrm{~h}$. The reaction mixture was quenched with water $(2 \mathrm{~mL})$ and then evaporated. The residue was diluted with ethyl acetate $(30 \mathrm{~mL})$ and washed with a saturated aqueous solution of sodium bicarbonate $(2 \times 30 \mathrm{~mL})$. The organic layer was dried over sodium sulphate, filtered and the solvent removed in vacuo. The residue was passed through a SCX-2 ion exchange column (10 g), eluting the product with $2 \mathrm{M}$ ammonia-methanol. Purification by flash column chromatography $\left[\mathrm{SiO}_{2}, \mathrm{MeOH}: \mathrm{DCM}, 0-15 \%\right]$ afforded the 
corresponding product (1a) as a white powder ( $87 \mathrm{mg}, 0.38 \mathrm{mmol}, 17 \%)$. Mp 102-103 ${ }^{\circ} \mathrm{C}$; vmax $/ \mathrm{cm}^{-1} 3311,2925,2211,1577,1476$ and $1456 ;{ }^{1} \mathrm{H}$ NMR $(500$ $\left.\mathrm{MHz}, \mathrm{CDCl}_{3}\right) \delta=7.18(\mathrm{dd}, J=8.5 \mathrm{~Hz}, 1 \mathrm{H}), 6.30(\mathrm{dd}, J=8.5,1.0 \mathrm{~Hz}, 1 \mathrm{H}), 6.20$ (dd, $J=8.5,1.0 \mathrm{~Hz}, 1 \mathrm{H}), 4.48(\mathrm{~s}, 2 \mathrm{H}), 3.96(\mathrm{dd}, J=9.0,3.7 \mathrm{~Hz}, 1 \mathrm{H}), 3.86$ (dd, $J=9.0,8.0 \mathrm{~Hz}, 1 \mathrm{H}), 3.14(\mathrm{ddt}, J=11.5,4.0,2.0 \mathrm{~Hz}, 1 \mathrm{H}), 3.10-2.97(\mathrm{~m}, 1 \mathrm{H})$, $2.78(\mathrm{~s}, 1 \mathrm{H}), 2.71(\mathrm{td}, J=11.9,2.7 \mathrm{~Hz}, 1 \mathrm{H}), 1.96-1.78(\mathrm{~m}, 1 \mathrm{H}), 1.76-1.62$ $(\mathrm{m}, 2 \mathrm{H}), 1.58-1.26(\mathrm{~m}, 3 \mathrm{H}) ;{ }^{13} \mathrm{C} \mathrm{NMR}\left(126 \mathrm{MHz}, \mathrm{CDCl}_{3}\right) \delta=161.0,151.1$, 134.5, 115.4, 107.6, 100.4, 86.7, 73.0, 55.4, 46.4, 28.3, 25.9, 24.1; LC-MS (TOF, $2.0 \mathrm{~min}$ ) Rt = $0.59 \mathrm{~min}$; m/z (ESI) $232(\mathrm{M}+\mathrm{H})$; Hi-Res LC-MS (ESI) $\mathrm{m} / \mathrm{z}$ calcd for $\mathrm{C}_{13} \mathrm{H}_{18} \mathrm{~N}_{3} \mathrm{O}(\mathrm{M}+\mathrm{H})$ 232.1450, found 232.1452. 2-Amino-6-(piperidin-2ylmethoxy)benzonitrile (1a) $(87 \mathrm{mg}, 0.38 \mathrm{mmol}$ ) was added portion-wise to a refluxing mixture of formic acid $(1.5 \mathrm{~mL}, 39.1 \mathrm{mmol})$ and conc. sulphuric acid $(0.09 \mathrm{~mL}, 1.7 \mathrm{mmol}) .30 \mathrm{~min}$ after the last addition, the mixture was cooled to 0 ${ }^{\circ} \mathrm{C}$ and poured onto ice-water. The aqueous was made basic with satd. $\mathrm{NaHCO}_{3}$ (aq.) and extracted with ethyl acetate $(20 \mathrm{~mL} \times 3)$. The organic layer was dried over sodium sulphate, filtered and the solvent removed in vacuo. Purification by ion-exchange chromatography [SCX-2, ammonia-methanol, 2M] afforded the corresponding product (2a) as a clear oil (81 $\mathrm{mg}, 0.31 \mathrm{mmol}, 83 \%)$. $\mathrm{vmax} / \mathrm{cm}^{-1}$ 2923, 1630, 1603, 1578, 1472 and 1461; 1H NMR $(500 \mathrm{MHz}$, $\left.\mathrm{CD}_{3} \mathrm{OD}\right) \delta=8.05(\mathrm{~s}, 1 \mathrm{H}), 7.65(\mathrm{dd}, J=8.0 \mathrm{~Hz}, 1 \mathrm{H}), 7.22(\mathrm{dd}, J=8.0,1.0 \mathrm{~Hz}$, $1 \mathrm{H}), 6.98(\mathrm{dd}, J=8.0,1.0 \mathrm{~Hz}, 1 \mathrm{H}), 4.21(\mathrm{dd}, J=9.0,3.5 \mathrm{~Hz}, 1 \mathrm{H}), 3.86(\mathrm{t}, J=$ $9.0 \mathrm{~Hz}, 1 \mathrm{H}$ ), $3.20-3.06(\mathrm{~m}, 2 \mathrm{H}), 2.76(\mathrm{td}, J=12.0,2.9 \mathrm{~Hz}, 1 \mathrm{H}), 1.93-1.81$ (m, 1H), $1.81-1.63(\mathrm{~m}, 2 \mathrm{H}), 1.50$ (dddd, $J=25.1,12.6,8.0,3.7 \mathrm{~Hz}, 2 \mathrm{H}), 1.35$ (tdd, $J=12.6,11.1,3.8 \mathrm{~Hz}, 1 \mathrm{H}) ;{ }^{13} \mathrm{C} \mathrm{NMR}\left(126 \mathrm{MHz}, \mathrm{CD}_{3} \mathrm{OD}\right) \delta=163.7,159.1$, 151.3, 148.5, 134.1, 118.4, 112.6, 109.2, 72.9, 55.3, 45.4, 27.2, 25.0, 23.6; LCMS (TOF, $2.0 \mathrm{~min}) \mathrm{Rt}=0.16 \mathrm{~min} ; \mathrm{m} / \mathrm{z}(\mathrm{ESI}) 260(\mathrm{M}+\mathrm{H})$; Hi-Res LC-MS (ESI) $\mathrm{m} / \mathrm{z}$ calcd for $\mathrm{C}_{14} \mathrm{H}_{18} \mathrm{~N}_{3} \mathrm{O}_{2}(\mathrm{M}+\mathrm{H}) 260.1399$, found 260.0805. A round-bottom flask was charged with 5-(2-piperidylmethoxy)-3H-quinazolin-4-one (2a) (80 $\mathrm{mg}, \quad 0.31 \mathrm{mmol}, \quad 1.0 \quad$ eq.) and (benzotriazol-1yloxy)tris(dimethylamino)phosphonium hexafluorophosphate (BOP) (1.3 eq.) before the addition of anhydrous acetonitrile $(2.5 \mathrm{ml})$. DBU (2.5 eq.) was added dropwise whilst stirring at $0{ }^{\circ} \mathrm{C}$. The reaction mixture was stirred at $0{ }^{\circ} \mathrm{C}$ for a further $5 \mathrm{~min}$ and then at r.t. for $19 \mathrm{~h}$. The reaction mixture was evaporated and the residue purified by flash column chromatography [ $\mathrm{SiO}_{2}$, EtOAc:Petrol, 50$80 \%$ ] to afford the title compound $3 \mathrm{a}$ as a yellow oil (53 mg, $0.22 \mathrm{mmol}, 71 \%$ ). vmax $/ \mathrm{cm}^{-1}$ 2923, 1630, 1603, 1578, 1472 and 1461; ${ }^{1} \mathrm{H}$ NMR $(500 \mathrm{MHz}$, $\left.\mathrm{CD}_{3} \mathrm{OD}\right) \delta=8.40(\mathrm{~s}, 1 \mathrm{H}), 7.62(\mathrm{dd}, J=8.0 \mathrm{~Hz}, 1 \mathrm{H}), 7.37(\mathrm{dd}, J=8.3,1.3 \mathrm{~Hz}$, $1 \mathrm{H}), 7.04(\mathrm{dd}, J=7.9,1.3 \mathrm{~Hz}, 1 \mathrm{H}), 5.28-5.20(\mathrm{~m}, 1 \mathrm{H}), 4.41(\mathrm{dd}, J=13.2,2.8$ $\mathrm{Hz}, 1 \mathrm{H}$ ), 4.30 (dd, $J=13.3,5.5 \mathrm{~Hz}, 1 \mathrm{H}$ ), 3.90 (ddt, $J=10.7,5.1,2.5 \mathrm{~Hz}, 1 \mathrm{H}$ ), $3.01(\mathrm{td}, J=12.9,2.4 \mathrm{~Hz}, 1 \mathrm{H}), 2.00(\mathrm{dtd}, J=10.1,4.1,2.3 \mathrm{~Hz}, 1 \mathrm{H}), 1.91-1.55$ $(\mathrm{m}, 5 \mathrm{H}) ;{ }^{13} \mathrm{C}$ NMR $\left(126 \mathrm{MHz}, \mathrm{CD}_{3} \mathrm{OD}\right) \delta=159.9,158.9,157.6,153.9,132.6$, 120.3, 114.6, 109.8, 73.3, 63.5, 49.2, 29.2, 25.2, 24.2; LC-MS (TOF, $4.0 \mathrm{~min}$ ) $\mathrm{Rt}=1.59 \mathrm{~min} ; \mathrm{m} / \mathrm{z}(\mathrm{ESI}) 242(\mathrm{M}+\mathrm{H})$; Hi-Res LC-MS (ESI) $\mathrm{m} / \mathrm{z}$ calcd for $\mathrm{C} 14 \mathrm{H} 16 \mathrm{~N} 3 \mathrm{O}(\mathrm{M}+\mathrm{H}) 244.1345$, found 244.1346.

42. Chen, X.; Chen, T.; Zhou, Y.; Han, D.; Han, L. B.; Yin, S. F. Org. Biomol. Chem. 2014, 12, 3802.

43. Addicott, C.; Lüerssen, H.; Kuzaj, M.; Kvaskoff, D.; Wentrup, C. J. Phys. Org. Chem. 2011, 24, 999.

44. MCF7 cell line GI50 > $10 \mathrm{uM}$ 
